\title{
Research on University English Teaching Mode based on Network Environment
}

\begin{abstract}
Computer aided language learning involves information technology, teaching design, teaching method improvement, construction of teaching resources and teaching environment. guided by the new educational and teaching theory of English Writing Teaching, this paper discusses how to more effectively use computer assisted language to design learning teaching model and method in the in higher vocational colleges, to create excellent teaching resources and environment, it can build a bridge between computer aided teaching and English writing teaching for English teachers.
\end{abstract}

Liwen WANG

School of Foreign Languages and Cultures

Ningxia University

Yinchuan, China
Keywords; Computer assisted language learning (CALL); Business English writing; Higher Vocational College;

\section{INTRODUCTION}

With the rapid development of education in China and its continuous improvement of education system and structure, more and more people recognize the importance of special teaching and learning activities in the higher vocational education and reform. Computer assisted language learning is a hot issue in current education reform, has become one of the most important factors to reform the traditional teaching and learning methods. How to use the computer assisted language learning, effectively use modern educational technology in the teaching of higher occupation education means, promote the higher occupation education teaching efficiency and improve the benefit, has become an important problem that each higher occupation education teachers must pay attention to.

Computer assisted language learning not only pays attention to the information technology, but also pay attention to the teaching design, teaching method improvement, construction of teaching resources and teaching environment. The author seeks in the education and teaching theory to guide the new, study business English Writing Teaching in higher vocational colleges how to more effectively application of computer assisted language learning teaching model design and method, to create excellent teaching resources and environment, we hope to erect a bridge between the practice of computer aided the teaching and Higher Vocational College English writing for the English teachers in Higher Vocational College.

\section{THE ADVANTAGES AND DISADVANTAGES OF INFORMATION TEACHING MODE}

1) Network learning resource have rich information source, large amount of knowledge, interactive strong function, which is conducive to enhance the initiative, learning enthusiasm, to cultivate the senior thinking and ability of the students. Because of the multimedia and network technology can provide friendly interface, an interactive learning environment, can carry on the chart, text, sound, like multi-sensory stimulation, according to comprehensive, hypertext, hyperlink mode of organization management of subject knowledge and teaching information, not only helps to stimulate students interest in learning and negotiating session, cooperation learning, is beneficial to students' active discovery, active exploration, is conducive to the creation of situations and get a lot of knowledge and maintain, establish development of associative thinking and establish the new old knowledge links, but also the formation and development of cognitive structure of students can promote students to construct current knowledge is very favorable.

2) Network learning resource have more flexible teaching mode, teaching activities, we can more fully meet the learning needs. With the help of multimedia and network technology support, learners can study English at home or in the office, can learn on the trip, each learner can be in the process of learning to accept suitable for learning ability and learning needs of their information data.

3) Teacher preparation is insufficient, easy to appear unable to control the teaching situation. In the information technology teaching mode, dominant control of teachers significantly reduces in the teaching, in the technique content rich teaching environment, each student may produce a variety of exceeding one's expectations of the situation and problems in the process of learning, teachers must respond differently in different situations. If the teachers' ability to manage a variety of information technology is imperfect, the class will be the case for lack of preparation or reactive ability is a bit poor, you may not have a good control of the classroom situation, this also brings limitations to the successful implementation of informatization teaching mode.

4) Network learning have higher demands on the teaching conditions, some schools are difficult to achieve.

\section{DESIGN OF ENGLISH WRITING TEACHING BASED ON COMPUTER ASSIST}

\section{A. Constitute of interactive teaching model}

Interactive English writing teaching mode is to help students achieve a teaching mode require by English writing teaching design based on computer assisted language learning. It emphasizes the importance of personalized, interactive teaching, autonomous and cooperative learning. As shown in figure 1. 


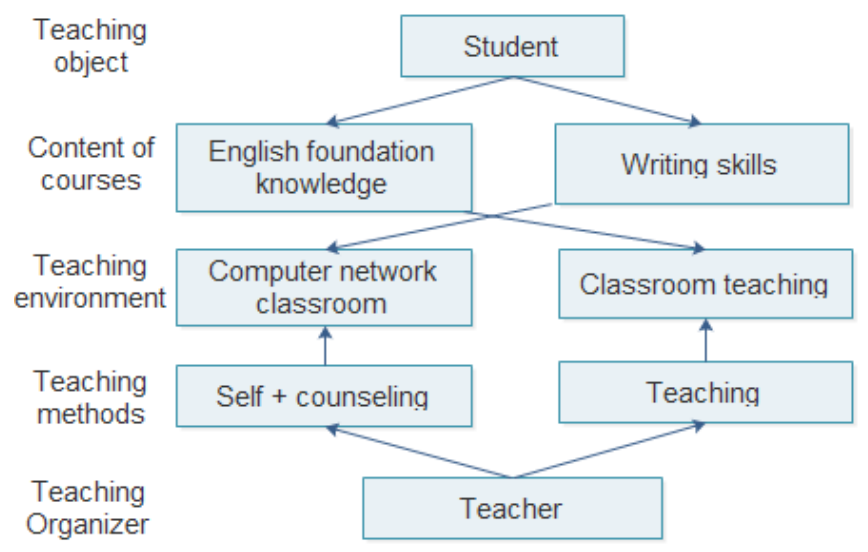

Fig.1 Structure of interactive teaching model

1). Transcribe English. This phrase summed up our teaching experience, it is applied in foreign language writing teaching must start from the copy. The first copy is copying letters and words written writing, practice is the main strokes, stroke order and other basic skills, the second copy is copying sentences, both calligraphy, practicing the. Copy run well, to write and lay the foundation. Also for future learning and memorizing new words laid the foundation. So the content of Chinese language teaching to copy the order and method, have strict regulations and requirements. The first to write is controlled writing, focusing on the training of writing skills and norms to master the structure of learning. Second write heavy content, let the students to express ideas.

2 ). control gradually. The process of copying itself is a control incremental. If in order to stimulate the students' interest and early to let students free composition. As a start let them write a Book contract. Students or copying, or in accordance with the Chinese habit heap of word phrases, in the habit of writing, the correct use of English and contain the negative transfer and other aspects are brought adverse effects. So, to emphasize control gradually, the initial use to write, must be obtained correctly, and control gradually is the correct path.

3 ). speaking and writing. Usually the English teachers to hear much attention, and wrote that is rarely used. Its basic structure is a word, sentence, and outline, namely write key words sequence and the corresponding content, but not write written. Then according to the outline to say, or to say after the written words. This is a good method to solve speechless and writing practice to say.

\section{B. Constitute of cooperative teaching mode}

Computer teaching model is divided into four parts under the network environment: instruction, discussion, search and collaborative learning. That is as shown in figure 2 .

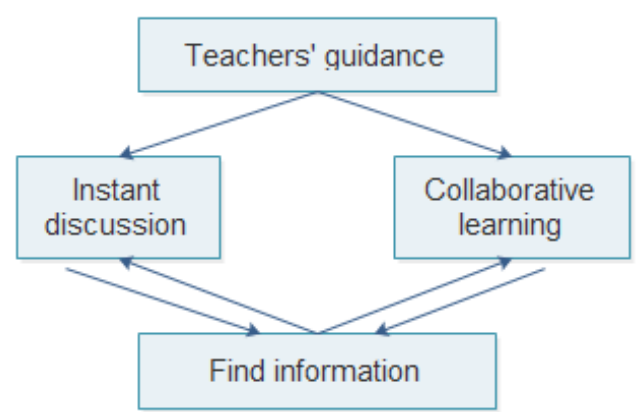

Fig.2 Constitute of cooperative teaching mode

Instant discussion aims to provide a virtual environment for students, create conditions of learning English and communicate with English, realize the interaction between teachers and students, students and students.

The process of English writing course collaborative teaching includes the following parts: assignments, discussion questions, Advisory Q \& A and finish the homework. That is as shown in figure 3.

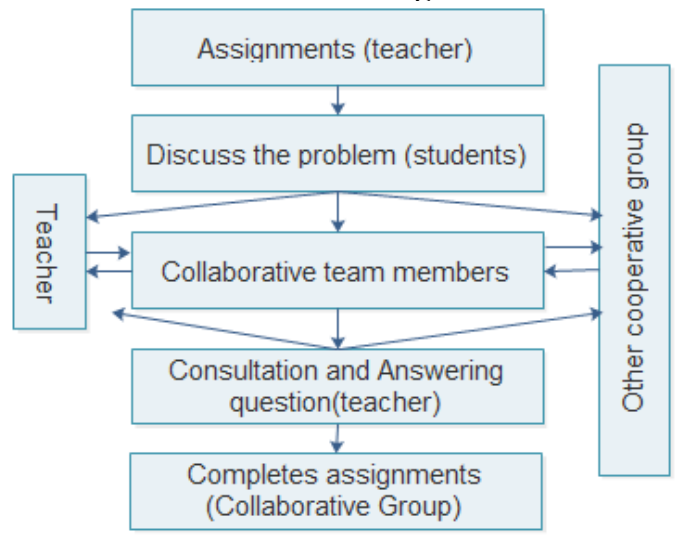

Fig. 3 The teaching process of collaborative teaching model

\section{Exploration of the teaching mode}

In our country, education network (or network teaching) is still a new thing, follow the education theory, how to design and develop network curriculum, how to implement the network teaching, how to give the learner to assist and guide the necessary, how to network education (or network teaching evaluation etc.), and many problems we should seriously think about and handle. On the current teaching situation of view, resource based collaborative inquiry and inquiry process based collaboration is very important, the network teaching platform plays a important role. To explore collaborative network teaching platform, is to provide a space or carrier for the students and the teachers and students exchange. In the network teaching platform, teachers can show themselves through it, students can also present their views through it; network teaching platform can provide clear theme communicate activities for teachers and students: teachers and students can communicate ideas, teachers and students can reach a consensus, a subject or task learning objectives of teacher can provide active environment to the students, and a goal 
of the theme to propose or accept feedback; network teaching platform can strengthen the interaction between teachers and students; students must achieve mission objectives through the activity, the teacher must have the essential relationship between the activities of the mission objectives provide meaningful internal feedback; network teaching platform can provide feedback on the activities, so that students can adjust the learning activities according to feedback.

1) Exploration of the teaching mode based on resource

In the network environment, Exploration of the teaching mode based on resource refers to students utilize various resources, to learn science content in the form of group participation, modeled on the process of science research, so as to master scientific content, at the same time then can experience, understand and apply scientific method, master a way to learn the scientific research ability and cooperation ability.

The Internet contains inexhaustible information, as long as the learners to master certain network communication skills, can retrieve the mechanism through various online, convenient and quick access to their knowledge needed for efficient learning. Collaborative learning is a student in the form of group participation, in order to achieve the common learning objectives, in certain incentive mechanism under the maximum individual cognitive achievement, all related behavior and cooperation and mutual assistance. Inquiry learning refers to the following process of science research to study the scientific content, so as student can master scientific content, at the same time can experience, understand and apply scientific method.

2) Exploration of the teaching mode based on process

Under the network environment, the process of collaborative inquiry need special support based on network teaching platform. Make full use of various functions of network teaching platform to support collaborative inquiry, except as a vehicle for communication, and the process also need to pay attention to the following questions:

A. teachers release teaching information using platform. Teaching information include the teaching content and the content of the record two categories. The teaching content is used to record the teacher prepared teaching materials, can be a part of electronic books, electronic notes, require students to query data URL address, prepare to deploy to the students' homework and hope the students discuss problems etc.. The teaching contents are usually media material, case, test database, network courseware and network course. Records of the content is generated in the learning process of students, including students' homework, work and learning process record etc..

B. teachers carry on the teaching process management. Such as course information management, teachers can manage the related teaching content and course information, also on students' learning process for tracking and monitoring. From the perspective of teaching evaluation, teachers can publish assignments in the network teaching platform, can also be on the students' homework make corrections and comments, and can the students homework to display, so that the students can check their own learning process and discussed the contents of the history through the network teaching platform, also can see someone good operation and works for the students, they review and learn from others are of great help. Automated assessment of teachers can make the network teaching platform for objective questions, make corrections to their subjective item.

\section{CONCLUSIONS}

The author adopts comparative experiment teaching method. We randomly selected two classes from English majors as the experimental class and the contrast class, respectively use the computer aided teaching means and the traditional writing teaching method. The teaching experiment has achieved good teaching effect.

In view of the problems existing in the experiment, the author put forward the following suggestions:

First, teacher training combined with student training. In order to make better use of computer assisted language learning, should carry on the short-term training to the teachers and the students, the teaching goal, the basic grasp of the operation of the device, effectively solve technical problems. If not through training, students will spend how many time to understand the operation of equipment, will be a waste of limited time and anxiety, even tired computer assisted learning.

Second, the use of advanced teaching equipment combine with the cultivation of students' learning interest. No matter we use any kind of teaching methods, the students' subject position cannot be ignored. If students are not interested in learning, lack of power, it is difficult to achieve good learning effects. Therefore, we should also pay attention to the cultivation of students' learning interest in the use of advanced teaching equipment.

Third, the combination of man-machine communication and interpersonal communication. The computer can't replace teachers, network teaching can't replace the classroom teaching. The students' autonomous learning ability is not ideal circumstances, teachers organize the classroom teaching is the key.

\section{REFERENCE}

[1] Zhou Binglan, Liu Xiaoqiong. Ten roles of teachers in Computer Assisted English writing [J]. Foreign language teaching, 2005 (2); 65-69.

[2] Wu Fang. Discussion on the University assisted multimedia network technology to English Writing Teaching [J]. Journal of Langfang Teacher's College (SOCIAL SCIENCE EDITION), 2009 (a): 109-110.

[3] Ma ring. The standard of English Writing [M]. Beijing: Peking University press, 2002:156.

[4] Liu Lili. Discussion on Network Multimedia Assisted English Writing Teaching in University [J]. Chinese power education, 2008 (4); 189-190

[5] Yu Meibing. University English writing teaching to explore the network mode [J]. Journal of Hubei University of Economics (HUMANITIES AND SOCIAL SCIENCES EDITION), 2009 (5) 198-199. 